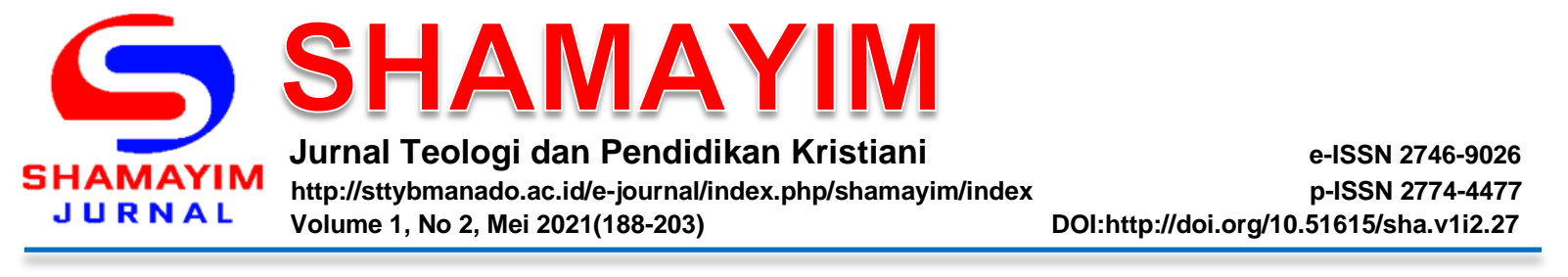

\title{
Peranan dan Kedudukan Orang Tua di Tengah Keluarga dan Gereja Sebagai \\ Pendidik
}

The Role and Position of Parents in The Middle of The Family and The Church As Educators

\author{
Ida Bagus Nyoman Widiartawan ${ }^{1}$, Talizaro Tafonao $^{2}$ \\ ${ }^{1,2}$ Sekolah Tinggi Teologi Real Batam \\ ${ }^{1}$ Nyoman.idabagus@gmail.com, ${ }^{2}$ talizarotafonao@gmail.com
}

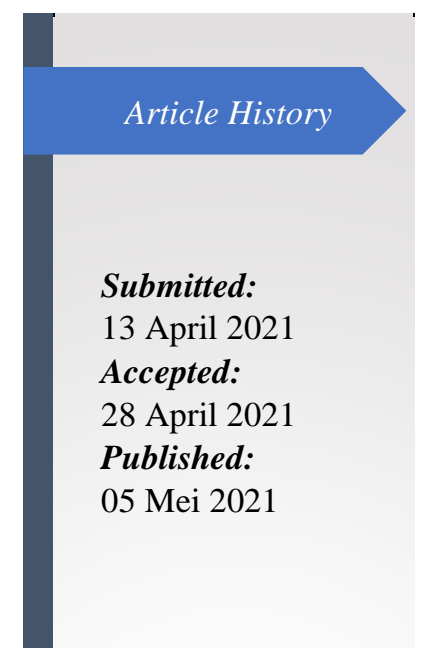

Keywords:

Parents, Family,

Church, Educator,

Psychology

\section{Kata Kunci:}

Orang Tua,

Keluarga, Gereja,

Pendidik,

Psikologis

\section{Abstract}

This study departs from the author's concern about the formation of parents, which the church has so far only underestimated. The church does not have a special interest in cultivating parents as educators in the family and church as explained in this article. The purpose of writing this article is to encourage the church to increase its role in coaching parents / the elderly. The method used is the literature research method by examining the role and influence of parents in the family and church. The analysis process carried out is to use various literary sources, both journals, books and other reliable reference materials to support the author's analysis. The results found in the review of this article have a very significant role in fostering and educating families. Based on these findings, it can be concluded that the negative assumptions regarding the role of parents so far can be ignored by the real explanation in this article.

\begin{abstract}
Abstrak
Kajian ini berangkat dari keprihatinan penulis terhadap pembinaan kepada orang tua yang selama ini hanya dipandang dengan sebelah mata oleh gereja. Gereja tidak memiliki perhatian secara khusus dalam membina orang tua sebagai pendidik dalam keluarga dan gereja sebagaimana penjelasan dalam artikel ini. Tujuan penulisan artikel ini adalah mendorong gereja untuk meningkatkan perannya dalam melakukan pembinaan orang tua/lansia. Metode yang digunakan adalah metode penelitian pustaka dengan mengkaji peran dan pengaruh orang tua dalam keluarga dan gereja. Proses analisis yang dilakukan adalah menggunakan berbagai sumber literatur-literatur baik jurnal, buku dan bahan referensi lainnya yang terpercaya untuk mendukung analisis penulis. Hasil yang ditemukan dalam kajian artikel ini memiliki peran yang sangat signifikan dalam membina dan mendidik keluraga. Berdasarkan hasil temuan tersebut dapat disimpulkan bahwa asumsi-asumsi negatif terhadap peran orang tua selama ini dapat ditepis dengan penjelasan riil dalam artikel ini.
\end{abstract}




\section{Pendahuluan}

Mewariskan iman kepada generasi penerus merupakan hal penting dalam iman orang Kristen, karena mengenal Allah dan mengasihi Allah adalah suatu perintah yang telah Allah berikan sejak dahulu. Namun realita yang terjadi hari ini menunjukkan banyak anggota keluarga justru meninggalkan gereja dan bahkan meninggalkan imannya. Dalam kajian yang pernah dilakukan oleh Tafonao menjelaskan bahwa ada beberapa sebab mengapa jemaat meninggalkan gereja, yakni masalah ekonomi dan jabatan. ${ }^{1}$ Dua hal ini menjadi pokok persoalan yang cukup mendasar saat ini sehingga seolah-olah gereja dan iman Kristen dirasa tidak lagi relevan dalam kehidupan masa kini. Pada hal Allah telah memberi tugas dan tanggung jawab dalam membimbing keluarga khususnya anak-anak. Banyak orang tua yang telah diberi tugas dan tanggung jawab dalam membimbing anakanak untuk mengenal Allah yang benar, namun tidak sedikit orang tua yang tidak mampu membawa kepada Allah. Ketiadaan peran orang tua dalam membina kerohanian anak sangat berdampak bagi pertumbuhan spiritual anak. ${ }^{2}$

Peranan orang tua sebagai pendidik sangat erat kaitannya dengan Pendidikan agama. Hal itu diperlukan untuk membawa setiap anak menjadi individu yang beriman dan takut akan Tuhan. Disinilah inti dari pendidikan, bahwa Pendidikan Agama Kristen memiliki muatan yang sama, yakni terjadinya proses belajar mengajar yang didasarkan pada Alkitab, yang berpusat kepada Kristus dan bertujuan untuk membimbing invididu melangkah dalam rencana dan tujuan Allah dalam hidup. ${ }^{3}$

Berdasarkan penjelasan ini, maka timbul suatu pertanyaan? Mengapa orang tua susah mengajarkan anak-anak tentang nilai-nilai kebenaran yang ada di dalam Alkitab?. Dalam kajian yang dilakukan oleh Wagiu menjelaskan bahwa indikasi tentang penyebab peran orang tua sebagai pendidik Agama Kristen tidak terealisasi dengan maksimal adalah karena gereja kurang memberikan edukasi tentang mandate Tuhan dalam Ulangan 6:4-9 serta orang tua lebih cenderung menghabiskan waktu di luar rumah, baik karena pekerjaan atau pelayanan, sehingga belum secara maksimal memberi teladan bagi anak-anaknya. ${ }^{4}$ Hal yang sama disampaikan oleh Tafonao bahwa rendahnya pengajaran Pendidikan Agama Kristen dalam keluarga, disebabkan karena orang tua tidak ada konsisten dalam membimbing anak-anak. ${ }^{5}$ Hal ini tidak bisa dibantah bahwa pola pendidikan anak dalam keluarga tergantung budaya yang dianut orang tua. ${ }^{6}$

Selaras dengan itu, teori Erikson mengatakan bahwa keberadaan hidup seseorang sampai akhir memiliki sejarah yang mempengaruhi perkembangan relasi anatara satu

1 Talizaro Tafonao, "Pendidikan Kewirausahaan Bagi Warga Gereja Di Era Digital," Visio Dei: Jurnal Teologi Kristen 2, no. 1 (2020): 127-146.

${ }^{2}$ Grace Putri Indah Sari, "Peran Gereja Dalam Memperlengkapi Orang Tua Membina Kerohanian Anak" (STT Seminar Alkitab Asia Tenggara, 2018).

${ }^{3}$ Nandari Pastica Wagiu, "Implementasi Peran Orangtua Menurut Ulangan 6:4-9 Dalam PAK Keluarga Di Gereja Masehi Injili Di Minahasa,” Jurnal Shanan 4, no. 2 (2020): 128-161.

${ }^{4}$ Ibid.

5 Talizaro Tafonao, "Peran Pendidikan Agama Kristen Dalam Keluarga Terhadap Perilaku Anak," Edudikara: Jurnal Pendidikan dan Pembelajaran 3, no. 2 (2018).

6 Ezra Tari \& Talizaro Tafonao, "Pendidikan Anak Dalam Keluarga Berdasarkan Kolose 3:21," KURIOS (Jurnal Teologi dan Pendidikan Agama Kristen) 5, no. 1 (2019). 
dengan yang lain dalam masyarakat serta budaya dan semua ini saling mendukung. ${ }^{7}$ Dengan demikian seolah-olah tugas orang tua semakin berat untuk mendidik anakanaknya. Bila dilihat dalam Kitab Amsal 17:6 mengatakan bahwa "Mahkota orang-orang tua adalah anak cucu dan kehormatan anak-anak ialah nenek moyang mereka."

Beranjak dari ayat tersebut, penting untuk dipahami bahwa Alkitab dengan tegas menyatakan hubungan atau ikatan antara orang tua dan anak itu, tidak hanya sekedar hubungan darah daging semata, tetapi ada hal yang diperlu dijaga, yaitu nama baik dan nilai-nilai yang ada dalam keluarga serta tanggung jawab. Situasi ini sangat mudah dilihat dalam kehidupan seorang ayah misalnya, ayah merasa bertanggung jawab dalam memenuhi kebutuhan jasmani dan urusan lainnya menjadi tanggung jawab seorang ibu. Menurut hemat Jailan bahwah hal ini merupakan tanggung jawab orang tua (Bapak dan Ibu) dalam memenuhi segala keperluan yang diperlukan oleh keluarga. ${ }^{8}$ Demikian juga anak-anak melakukan pekerjaan dalam rumah sebagai bentuk tanggung jawabnya kepada orang tua. Sekalipun ada diantara anak-anak yang beranggapan bahwa aktifitas yang dilakukan tersebut adalah atas perintah orang tua dan bukan karena suatu bentuk ketundukan kepada orang tua.

Bowlby dalam Krismawati mengatakan bahwa hubungan alami yang dimiliki oleh seorang anak adalah ikatan yang kuat kepada ibunya. Sesuatu yang penting telah ditemukan menghasilkan pola prilaku yang berbeda, apakah itu terjadi karena terprogram dalam lingkungan yang berbeda, namun kehidupan yang terjadi dalam bulan-bulan pertama kelahiran seorang anak telah membentuk ikatan yang kuat lebih kepada ibunya. ${ }^{9}$

Berangkat dari penjelasan tersebut di atas, maka dalam tulisan ini penulis memfokuskan melihat peranan orang tua khusunya ibu yang memasuki kelompok lanjut usia. Sejauh pengamatan penulis dalam melayani selama ini, bahwa tidak ada yang paling istimewa yang rindukan oleh orang tua dari anak-anaknya selain anak, menantu dan cucu datang dengan sungguh-sungguh kepada Tuhan. Salah satu contoh gambar keluarga Kristen yang ideal dapat dilihat dalam kehidupan keluarga Filipus KPR 21:7-8. Bagi keluarga modern ada istilah bahwa ada rumah (house); tetapi tidak ada keluarga (home); hal ini menyedihkan. Home yang sebenarnya dimana semua isi keluarga menjadi satu dalam iman. ${ }^{10}$

Pendiri Bala Keselamatan, William Booth mengatakan, "Kita harus membuat anakanak belajar lebih dahulu tentang kebaikan sebelum mereka belajar tentang kejahatan dari Iblis". ${ }^{11}$ Oleh karena itu, sudah seharusnya mereka yang dewasa harus menuntun dan membawa keluarganya kepada Yesus supaya mereka belajar hidup seperti Yesus.

\footnotetext{
${ }^{7}$ Yeni Krismawati, "Teori Psikologi Perkembangan Erik H. Erikson Dan Manfaatnya Bagi Tugas Pendidikan Kristen Dewasa Ini," Kurios 2, no. 1 (2018): 46.

${ }^{8}$ M. Syahran Jailani, “Teori Pendidikan Keluarga Dan Tanggung Jawab Orang Tua Dalam Pendidikan Anak Usia Dini," Nadwa 8, no. 2 (2014): 245.

9 John Bowlby, A Secure Base: Clinical Applications of Attachment Theory (USA and Canada: Routledge, 1988).

${ }^{10}$ Woo Young Kim, Yesus Jawaban: Kumpulan Kotbah (Jakarta: BPK Gunung Mulia, 2005).

11 Ibid.
} 
Tujuan penulisan ini adalah untuk meningkatkan peranan gereja dalam membina orang tua sebagai pendidik dalam keluarga dan gereja. Sebagai rumusan masalah adalah siapakah yang digolongkan sebagai kelompok orang tua? Bagaimana peran gereja dalam mempersiapkan kelompok orang tua sebagai Pendidik di tengah keluarganya?

Keluarga adalah masa depan sebuah bangsa yang kuat. Ketahanan suatu bangsa terletak pada kekuatan keluarga. Kehancuran sebuah keluarga tidak lagi dipandang sebagai sesuatu yang tabu atau menimbulkan malu pada masa modern ini. Solusi dalam kegagalan sebuah pernikahan adalah membangun pernikahan yang baru. Mungkin demikian konsep semua orang yang hidup di luar Tuhan.

Dibutuhkan satu orang yang kuat, satu orang yang berhikmat, satu orang yang takut Tuhan cukup untuk menjaga ketahanan sebuah keluarga. Penulis melihat bahwa orang tua yang lanjut usia masih memiliki potensi untuk menjadi "the person" tersebut.

\section{Metode Penelitian}

Dalam penulisan artikel ini, metode yang digunakan adalah metode penelitian pustaka (librabry research atau telaah literature). Menurut penjelasan dari Sari bahwa penelitian kepustakaan merupakan suatu studi yang digunakan dalam mengumpulkan informasi dan data dengan bantuan berbagai macam material yang ada di perpustakaan seperti dokumen, buku, artikel dan majalah. ${ }^{12}$ Berdasarkan penjelasan itu, maka selanjutnya penulis melakukan analisis dengan cara memperbanyak informasi dari berbagai sumber-sumber serta membandingkan, menemukan dan tidak dalam bentuk angka. Proses analisis yang dilakukan adalah menggunakan berbagai sumber literaturliteratur baik jurnal, buku dan bahan referensi lainnya yang terpercaya untuk mendukung analisis penulis.

\section{Hasil dan Pembahasan}

\section{Hubungan Orang Tua dan Anak}

Berbicara seputar ikatan hubungan ibu dan anak, tentunya semua orangtua pasti mengasihi anaknya. Hubungan psikologis yang baik akan berdampak kepada pertumbuhan anak-anaknya, baik fisik dan emosional. Sebuah studi menemukan bahwa hubungan yang kurang harmonis antara anak dan orang tua akan memberikan dampak buruk dan perkembangan yang tidak sehat bagi anaknya hingga dewasa. ${ }^{13}$

Seperti kata pepatah, cinta kasih orang tua sepanjang masa dan cinta kasih anak sepanjang galah. Artinya, hubungan anak hanya sebatas jarak setelah menjauh dan meninggalkan orangtuanya maka bisa saja sikap anak menjadi berbeda. Sementara tidaklah demikian bagi orangtua. Maxwell menulis dalam sebuah bukunya, untuk beberapa saat pikiran saya selalu terarah kepada ibu saya. Hal itu sangat memahitkan. Setiap kali aku

12 Milya Sari and Asmendri, "Penelitian Kepustakaan (Library Research) Dalam Penelitian Pendidikan IPA," Penelitian Kepustakaan (Library Research) dalam Penelitian Pendidikan IPA 2, no. 1 (2018): 15.

${ }^{13}$ Sugiyono, "Perspektif Psikologi Keluarga," Journal of Chemical Information and Modeling 53, no. 9 (2013): 1689-1699. 
mengingat dia saya selalu tersenyum, karena cintanya yang tidak berpamrih. Tapi itu juga membuat saya bersedih karena dia telah meninggal pada tahun 2009, dan saya masih merindukannya. ${ }^{14}$ Dalam buku yang sama, Maxwell juga mengungkapkan sosok Ruth yang berjalan mengikuti kata hatinya, seperti dijelaskan di bawah ini.

"My Heart for Naomi Outweighed Everything Else." Keputusanku adalah untuk tetap bersama Naomi. Segera kami meninggalkan Moab untuk pergi ke Yehuda, tanah kelahirannya. Saat kami tiba di Yerusalem, tidak ada sedikitpun harapan. Aku tahu naomi sudah menyerah. Dia pikir Tuhan telah meninggalkannya. Saya tahu bahwa dia telah kembali ke rumah untuk mati. Jadilah itu. Jika dia akan mati, saya akan mati bersamanya. Aku akan dimakamkan di sampingnya, di antara bangsanya, yang sekarang menjadi bangsaku. Saya tidak peduli apa yang terjadi pada saya. Hati saya merasakan hal-hal yang tidak dapat dilihat oleh mata saya, dan ia mengetahui apa yang tidak dapat dipahami oleh pikiran saya. Naomi sangat baik padaku, bagaimana mungkin aku tidak baik padanya? ${ }^{15}$

Dibandingkan dengan kehidupan normal, maka kita bisa melihat sebuah hubungan yang tidak lumrah telah terbangun dalam diri Ruth. Cinta kasih Ruth kepada Naomi tergambar dengan jelas pada kisah ini. Hal ini membuktikan bahwa cinta kasih itu adalah merupakan kebutuhan yang fundamental, meskipun ada juga yang punya pandangan berbeda. Hal ini juga membawa seorang pujangga terkenal Khalil Gibran berpendapat bahwa "Cinta kasih hanyalah sebuah kemisterian." Cinta kasih itu sangat erat dalam kehidupan dan tidak bisa dipisahkan. Tidak pernah terlintaspun orang berpikir bahwa cinta kasih itu tidak penting. ${ }^{16}$

"My Heart for Naomi Led Me to Boaz." Ketika kami tiba di tanah air lama Naomi, saya tahu saya perlu melakukan sesuatu agar kami tidak kelaparan. Tuhan dalam kebaikan hati-Nya yang mengatakan kepada umat-Nya untuk selalu meninggalkan tepi ladang tanpa dipanen bagi orang-orang seperti Naomi dan saya. Jadi saya pergi untuk mengumpulkan biji-bijian selama panen. Saya percaya itu bukanlah kebetulan semata sampai tiba di ladang Boas. Pada saat seseorang membuat keputusan untuk menghormati Tuhan dengan hati tulus, Tuhan membimbing Anda dengan tangan-Nya. Saya tidak mengetahuinya, tetapi Tuhan telah memberi jalan bagi saya. Boas telah mendengar tentang saya, dan dia melindungi saya seperti saya adalah anggota rumahnya. Dia memberi saya makan dan dia bahkan memberi saya biji-bijian ekstra untuk dibawa kembali ke Naomi. ${ }^{17}$

Tuhan berfirman dalam Mazmur 25:10, "Segala jalan TUHAN adalah kasih setia dan kebenaran bagi orang yang berpegang pada perjanjian-Nya dan peringatan-peringatanNya." dan terbukti bahwa keputusan untuk mengikuti Naomi pulang ke kampung halamannya bukan sebuah kesalahan yang fatal. Melainkan telah membawa mereka berdua kepada sosok Boas yang menjadi tempat perlindungan dimasa kesusahan.

\footnotetext{
${ }^{14}$ John C. Maxwell, Wisdom from Women in the Bible: Giants of the Faith Speak Into Our Lives (USA: FaithWords, 2015).

${ }^{15}$ Carolyn Custis James, The Gospel of Ruth Loving God Enough to Break the Rules (Michigan: Zondervan, 2011).

${ }^{16}$ Sugiyono, "Perspektif Psikologi Keluarga."

${ }^{17}$ James, The Gospel of Ruth Loving God Enough to Break the Rules.
} 
“My Heart for Naomi Led Me to Hope." Ketika naomi mengetahui bahwa saya telah menghabiskan hari itu di ladang Boas, kerabatnya, dia menyadari bahwa Tuhan menyediakan bagi kami. Itu menghidupkan kembali harapannya dan dia menjadi hidup kembali. ${ }^{18}$ Menurut Moen bila diibaratkan buku Ruth adalah cerita sekolahan maka Naomi adalah sebagai kepala sekolahnya. Dalam Rut, Naomi pertama kali tampil dalam Ruth 1:2; kemudian kita bisa mengenal Naomi dari setiap perkataannya yang dicatat (Rut 1:8-15; 20$21 ; 2: 2 ; 19-22 ; 3: 1-4 ; 16,18)$ dan kita bisa terus mengikuti kisahnya hingga satu kali ia memangku seorang bayi laki-laki dan diberi nama Obed, dialah ayah Isai, ayah Daud (Rut 4:16). Kita juga mengetahui kehidupan batin Naomi; kesedihan, kepahitan, kepasrahan, dan transformasi kepada harapan baru. Identitas Naomi berubah berdasarkan narasi; dia pindah dari istri Elimelech menjadi seorang janda yang berduka dan getir serta ibu mertua yang mengundurkan diri; kemudian dia menjadi pengatur rayuan dan akhirnya menjadi perawat. Semua karakteristik ini membuatnya menjadi karakter yang utuh. ${ }^{19}$

Naomi membawa seluruh kepedihannya kepada Tuhan (Rut. 1:3; 20-21). Dia mengerti bahwa semua kejadian yang dialami akibat seijin Tuhan. Naomi banyak bertanya kepada Tuhan dalam tulisan ini. Kedekatan Naomi dan Rut membawa kita kepada pertanyaan bagaimana sesungguhnya hubungan kedua perempuan ini. Karena perjuangan luar biasa mereka mampu bertahan hidup melawan segala rintangan di tengah masyarakat, komunitas umat Allah, dan sistem hukum. Seperti yang kita duga, ceritanya sarat dengan tema feminin. Janda dan pernikahan, pengasuh, dan hubungan pria/wanita semuanya muncul.

Naomi dengan caranya sendiri dapat diidentifikasi sebagai seorang teolog, karena inti dari ceritanya adalah pencariannya untuk mengenal dan berjalan dengan Tuhan. Pernyataan-pernyataannya termasuk dalam arena diskusi teologis yang mendalam, di mana ia memiliki banyak hal untuk ditawarkan. Ruth tidak lagi bisa kita anggap sebagai kitab yang ringan di antara kitab lain dalam Alkitab. Kitab ini bukanlah selingan romantis yang tersirat di antara tulisan-tulisan kenabian dan sejarah yang lebih signifikan untuk meredakan ketegangan yang ditimbulkan oleh kisah-kisah buruk tentang umat Allah yang mengalami kemerosotan moral. Kitab Ruth ini berdiri sendiri sebagai kontribusi penting untuk pemahaman kita tentang Tuhan. ${ }^{20}$

Kitab Ruth ini baik untuk dipahami bagi kaum yang lanjut usia, karena didalamnya ada dua hal penting yang bisa kita pelajari. Pertama, Tuhan adalah pahlawan sejati dari kisah ini. Bagaimanapun Ruth digambarkan dalam kitab ini, bagian yang terpenting adalah apa yang ingin Tuhan sampaikan kepada kita mengenai diri-Nya sendiri. Kedua, harta warisan dari Hawa. Sebagai blueprint ciptaan dari Tuhan dari kaum perempuan, menjadi kunci yang penting untuk memahami Naomi dan Ruth. Tuhan menciptakan wanita menurut rupa dan gambarNya - untuk mengenalNya, menjadi seperti Dia, dan untuk mewakili Dia dalam interaksi mereka dengan orang lain. Sebagai teolog, Naomi dan Ruth

\footnotetext{
18 Ibid.

19 Kristin Moen Saxegaard, Character Complexity in the Book of Ruth, Volume 47. (Tubingen, Germany: Mohr Siebeck, 2010).

${ }^{20}$ James, The Gospel of Ruth Loving God Enough to Break the Rules.
} 
memahami bahwa dunia diselesaikan oleh Tuhan. Misi mereka adalah untuk memusatkan diri pada Dia - untuk mempercayai Dia dan untuk memajukan kerajaanNya.

\section{Tahapan Perkembangan Psikososial Anak}

Selain memahami hubungan orang tua dan anak, maka bagian selanjutnya adalah memahami tahapan perkembangan psikososial. Dalam pengamatan penulis melihat bahwa sepanjang hidup manusia mengalami tahapan perkembangan mulai dari bayi sampai dengan usia lanjut. Ada delapan tahapan yang masing-masing mempunyai nilai kekuatan yang membentuk karakter positif atau sebaliknya, namun setiap tahapan itu mempunyai sifat sosial dan psikologis yang sangat berarti bagi perkembangan kelangsungan masa depan seseorang. ${ }^{21}$ Berikut ini adalah tahapan dalam proses psikologi, yaitu:

Pertama, Usia 0-2 tahun. Pada usia ini memiliki titik awal dengan pembentukan karakter. Setiap anak bayi selalu mempercayai orang lain khususnya terhadap kebutuhannya. Oleh karena itu orang tua memiliki peranan penting untuk membantu perkembangan setiap anak. Selain itu hendaknya keluarga mencipatakan lingkungan keluarga yang harmonis dan sehat agar anak-anak bertumbuh dan berkembang sesuai usianya. Salah satu masalah terbesar dalam kehidupan anak-anak selama ini adalah adanya persepsi yang diciptakan pada diri anak yang dilakukan oleh orang tua sendiri, sehingga anak-anak merasa tertolak. $^{22}$

Kedua, Usia 2-3 tahun. Diusia seperti ini anak sudah mulai merasa malu dan ragu. Oleh karena itu, perhatian dari keluarga sangat penting untuk mendukung anak dalam melakukan setiap aktifitas. Apresiasi dari keluarga dalam menumbuhkan keinginan atau kehendak anak sangat penting, dimana anak belajar menjadi bebas untuk mengembangkan kemandiriannya, seperti balajar makan, berpakaian sendiri, berbicara atau mendapat jawaban dari sesuatu yang ditanyakannya. ${ }^{23}$

Ketiga, Usia 3-6 tahun. Anak pada tahap ini belajar menemukan keseimbangan antara kemampuan yang ada dalam dirinya dengan harapan atau tujuan. Itulah sebabnya anak lebih cendrung menguji kemampuannya tanpa mengenal potensi yang ada pada dirinya. Konflik yang terjadi adalah inisiatif atau terbentuknya perasaan bersalah. ${ }^{24}$

Keempat, Usia 6-12 tahun. Hala-hal yang dikembangkan pada usia ini adalah melatih untuk berkerja aktif. Sebab kekuatan yang perlu ditumbuhkan adalah kompetensi atau terbentuknya berbagai keterampilan. Namun ada perlu dihindari oleh orang tua adalah membandikngkan kemampuan anak dengan teman sebaya. Membandingkan kemampuan anak dengan yang lain bukan solusi yang terbaik bagi anak tetapi yang terpenting disini adalah memupuk kepercayaan percaya diri pada anak. ${ }^{25}$

${ }^{21}$ Krismawati, "Teori Psikologi Perkembangan Erik H. Erikson Dan Manfaatnya Bagi Tugas Pendidikan Kristen Dewasa Ini."

${ }^{22}$ Ibid.

${ }^{23}$ Ibid.

24 Ibid.

25 Ibid. 
Kelima, Usia 12-20 tahun. Pada usia ini anak-anak memasuki usia remaja dimana identitas diri baik dalam lingkungan sosial maupun dunia kerja mulai diterapkan. Tetapi yang menarik dibagian ini adalah mereka sudah mulai mencari jati diri, sehingga anak berada pada tahap persimpangan antara masa kanak-kanak dengan masa dewasa. Persoalan utama dalam masa ini adalah pengakuan terhadap diri sendiri dan orang lain. Dengan melihat kondisi seperti ini maka orang tua perlu memberi pemahaman kepada mereka, agar anak-anak tidak terjebak dengan iklan-iklan yang cenderung menjerumus pada hal-hal negatif. $^{26}$

Keenam, Usia 20-40 tahun. Pada tahap ini kekuatan dasar yang dibutuhkan adalah kasih. Sebab tanpa kasih yang mengimbangi pada tahap ini akan terjadi berbagai konflik dalam diri seseorang seperti merasa keterasingan atau kesendirian. Oleh karena itu, peranan keluarga dan sahabat sangat diharapkan demi menumbuhkan rasa optimis. Jika hal ini tidak dipenuhi, maka akan memunculkan suatu perasaan yang sepi, dan tidak berhargaan. $^{27}$

Ketujuh, Usia 40-65 tahun. Pada usaia seperti ini banyak diperhadapkan dengan tugas utama. Jelas usia seperti ini adalah usia produktif yang disertai dengan tanggung jawab dalam bidangnya. Sehingga tuntutan untuk berhasil sangat tinggi, namun tidak tertutup kemungkinan terjadinya konflik mendidik. Salah satu konflik utama pada tahap ini ialah generatifitas vs stagnasi. Hal utama yang dibangun disini adalah kepedulian. ${ }^{28}$

Kedelapan, Usia 65 tahun. Pada usia 65 tahun telah memasuki usia lanjut. Hal yang terjadi diusia ini adalah adanya penurun pada kesehatan. Selain itu memiliki segudang pengalaman seperti keberhasilan dan kegagalan. Maka kebutuhan yang mendasar pada usia ini adalah dihargai. Bila hal ini tidak tercapai maka yang terjadi konflik. ${ }^{29} 082326162347$

\section{Perkembangan Rohani Orang Percaya}

Pertumbuhan rohani yang benar akan membawa orang kepada hubungan yang lebih kuat baik dengan Tuhan atau sesama. Namun perlu diketahui bahwa pertumbuhan rohani bukan sesimpel 1,2,3,4...60 persen. Bersama dengan berjalannya waktu dan usia yang sudah mencapai pertengahan hidup, kita menyadari bahwa pertumbuhan rohani sama sulitnya dengan kehidupan ini. Menurut pemahaman Gunawan bahwa kedewasaan rohani merupakan sebuah kondisi yang harus dialami oleh setiap orang Kristen, ${ }^{30}$ melalui relasi, ketaatan, setia dan percaya kepada Yesus Kristus. Sekalipun pada akhirnya masih ditemukan orang-orang Kristen yang belum memiliki pemahaman yang siginifikan tentang kedewasaan rohani. Dalam Surat Ibrani menggambarkan mengatakan "Sebab sekalipun kamu, ditinjau dari sudut waktu, sudah seharusnya menjadi pengajar, kamu masih perlu lagi diajarkan asas-asas pokok dari penyataan Allah, dan kamu masih memerlukan susu,

\footnotetext{
${ }^{26}$ Ibid.

27 Ibid.

${ }^{28}$ Ibid.

${ }^{29}$ Ibid.

${ }^{30}$ Agung Gunawan, "Pemuridan Dan Kedewasaan Rohani," Jurnal Theologia Aletheia 19, no. 12
} (2017). 
bukan makanan keras. Sebab barangsiapa masih memerlukan susu ia tidak memahami ajaran tentang kebenaran, sebab ia adalah anak kecil" (Ibr. 5:12-13). Akibat lemahnya pemahaman tentang kedewasaan dalam rohani ini tidak sedikit orang-orang Kristen meninggalkan iman percayanya kepada Yesus sebagaimana penjelasan dalam artikel ini sebelumnya.

Seorang penginjil terkenal Billy Sunday mengatakan, "Going to church doesn't make you a Christian any more than going to a garage makes you an automobile." 31 Yang dimaksudkan disini adalah banyak orang Kristen yang rajin keluar masuk gereja, namun tidak pernah sampai mengalami kedewasaan ataupun pengalaman rohani dalam kehidupan mereka. Dengan kata lain hidup mereka sebelum dan sesudah ke gereja tetap sama. Sebagai orang Kristen sudah seharusnya memiliki pemahaman yang baik mengenai makna Amanat Agung dalam Matius 28:18-20, banyak pandangan mengenai perintah ini dan salah satunya dapat dipertimbangkan bahwa Yesus mau kita semua melakukan misi, menjadikan orang murid Yesus dan membaptis mereka yang percaya. Bagaimana caranya? Barangkali itu menjadi pertanyaan orang Kristen, karena ayat ini terlihat seperti perintah singkat "go and show"

Yesus tidak mengajarkan kepada kita sebuah metode "learn-as-you-go" untuk menjalankan amanat tersebut. Dia dibesarkan dalam rumah tangga orang-orang yang hidup dalam Shema, doa Ibrani kuno yang ditemukan dalam Ul 6: 4-9. Shema artinya dengarkan, yang mengandung konotasi 'Hei, kamu! Iya kamu! Dengarkan dan patuhi!" Seolah-olah mendengar dan mematuhi adalah satu kata yang tidak terputus. Ketika Yesus diangkat, Dia memerintahkan kepada para pengikutnya untuk pergi sampai ke ujung dunia dan menjadikan mereka murid. Janji-Nya disini adalah mereka akan diberikan kuasa. Janji ini mengandung makna, mereka bebas untuk menjalankan perintah-Nya untuk mencintai Tuhan sepenuhnya, hati, jiwa, pikiran, dan kekuatan, dan kemudian mengasihi-Nya dengan cara mencintai sesama mereka. Ada kemudahan dibuat Tuhan bagi kita saat ingin mengasihi Tuhan, itu bisa dilakukan juga dengan cara mengasihi sesama manusia. Dan tentu saja hal ini bisa dilakukan setiap hari dalam kehidupan kita. ${ }^{32}$

Di tengah kehidupan modern saat ini, pemuridan bisa saja dilakukan melalui bermacam cara. Diantaranya dapat melalui media sosial seperti Youtube, Instagram, Facebook ataupun Tweeter. Tidak ada yang salah dengan teknologi tersebut, namun terkadang apa yang ditampilkan lewat media tersebut adalah bentuk kehidupan yang baikbaik saja. Sama halnya dengan sebuah media digital yang bisa diedit, dipotong dan ditambahkan, maka begitu juga kehidupan pembicaranya agar terlihat selalu baik ketika tampil di media sosial. Sehingga membuat orang terkagum-kagum, tapi apakah orangorang dan Tuhan akan kagum bila mengetahui kehidupan yang sesungguhnya? Maka pemuridan yang terbaik musti bergerak dari gereja lokal untuk mempersiapkan para muridmurid yang akan menjalankan misi Amanat Agung itu.

${ }^{31}$ Michelle Van Loon, Becoming Sage: Cultivating Meaning, Purpose, and Spirituality in Midlife (Moody Publishers, 2020).

32 Ibid. 
Kedewasaan rohani bukan persoalan kemampuan mengatasi masalah, namun menggambarkan sebuah proses pertumbuhan untuk menjadi seperti Krisus didalam setiap aspek kehidupan. Hal itu ditandai dengan peningkatan terus-menerus dalam penyerahan hidup melalui teladan dalam pelayanan Yesus dan hidup dalam pimpinan oleh Roh Kudus. ${ }^{33}$ Kesalahan yang bodoh, sikap berbelat belit, dan dosa selama kita hidup dapat diubah menjadi sebuah kebijaksanaan saat kita menyerahkan diri kita kepada Tuhan. Tujuannya bagi kita adalah untuk direformasi menjadi gambar Anak-Nya yang terkasih (2. Kor 3:18).

Terdapat hubungan parallel antara jasmani dengan kehidupan dan perkembangan rohani saat kita mau bertumbuh dalam Iman. Paulus menjelaskan bahwa "Ketika aku kanak-kanak, aku berkata-kata seperti kanak-kanak, aku merasa seperti kanak-kanak, aku berpikir seperti kanak-kanak. Sekarang sesudah aku menjadi dewasa, aku meninggalkan sifat kanak-kanak itu. Karena sekarang kita melihat dalam cermin suatu gambaran yang samar-samar, tetapi nanti kita akan melihat muka dengan muka. Sekarang aku hanya mengenal dengan tidak sempurna, tetapi nanti aku akan mengenal dengan sempurna, seperti aku sendiri dikenal". (1 Kor.13:11-12).

Berdasarakan ayat ini dapat disimpulkan bahwa dalam membina orang tua yang sudah lanjut usia sangat memerlukan cara-cara yang mudah dimengerti dan diterima bagi mereka yang memiliki pola berpikir pada usia itu. Latar belakang yang berbeda-beda, perbedaan masalah yang dihadapi ataupun kebutuhan hidup yang tidak sama menuntut kita untuk bisa melahirkan materi yang lebih efektif dan efisien. Keadaan para orang tua yang sudah berumur khususnya bagi mereka yang tidak memiliki pasangan dan anak-anak Kondisi seperti ini mereka merasa terabaikan. Namun dalam keadaan ini, lebih mudah bagi para pelayan gereja untuk memotivasi dan berharap total kepada Tuhan sebagai satusatunya penolong yang sejati.

Kisah kehidupan Raja Daud bisa menjadi contoh bagaimana jiwa yang berseru-seru untuk mencari Tuhan dan menerapkan dalam beberapa konsep: ${ }^{34}$

Tahap 1: Tuhan, aku percaya kepada-Mu (God, I believe in You). Orang-orang Kristen yang bertumbuh dalam keluarga Kristen, mereka lupa kapan mereka pertama kali mengenal akan Tuhan. Bila kita bertumbuh dalam keluarga Kristen, kita akan memiliki kesadaran akan mengenal Tuhan pada masa kecil kita. Namun mereka yang bertumbuh diluar iman Kristen seperti penulis sendiri, maka waktu itu adalah ketika menaikkan sebuah doa atau membuat komitmen hidup yang menjadikan status kita dari "hilang" menjadi "ditemukan".

Tahap 2: Tuhan, aku adalah milik-Mu (God, I belong to You). Orang percaya terus bertumbuh ke tahap selanjutnya menjadi iman muda. Tahap kedua ini adalah mengenai peraturan yang tertulis dan bagaimana kita menghidupinya dalam persekutuan. Raja Daud diutus ke tengah pertempuran antara umat Allah dengan orang Filistin serta Goliat bukan untuk berjuang tetapi untuk melihat keadaan saudara-saudaranya. Tapi yang terjadi

\footnotetext{
${ }^{33}$ Ibid.

${ }^{34}$ Ibid.
} 
tidaklah demikian, Daud dipilih Tuhan dan dipakai Tuhan untuk mengalahkan Goliat. Daud sadar hidupnya adalah milik Tuhan yang sudah menyelamatkannya selama ini dari hewan buas saat menggembalakan domba-domba ayahnya, dia yakin Tuhan yang sama juga telah menyerahkan Goliat ke dalam tangannya.

Tahap 3: Tuhan, saya melayani Engkau (God, I'm working for You). Tahap selanjutnya lebih fockus kepada pelayanan sesuatu untuk Tuhan. Mau mengambil tugas dan tanggung jawab yang lebih besar dalam komunitas pelayanan. Janet Hagberg dan Robert Guelich memberi catatan tanda orang beriman cenderung penuh dengan kegiatankegiatan; yang positif dan dinamis; dan berpusat pada area Iman Kristen.

Tahap 4: Tuhan dimanakah Engkau? Aku sendirian di tengah kegelapan (God, where are you? I'm alone in the dark). Jika kita terus bertumbuh, maka kita akan sampai kepada situasi seperti digambarkan Yohanes mengenai salib sebagai "the dark night of the soul". Dark night ini adalah suasana kehilangan atau disorientasi. Hal ini juga bisa berupa kehilangan orang yang dicintai, keluarga, tetangga, sahabat atau anak-anak mulai meninggalkan rumah.

Tahap 5: Tuhan, saya siap untuk menyerahkan semuanya yang Engkau berikan (God, I'm ready to pass along what You've given to me). Bila kita bertahan dalam masa kegelapan pada tahap keempat, maka kita akan mempunyai pandangan yang baru. Kita mungkin melihat iman kita tidak sekuat tahap 2 atau 3, bahkan kehilangan ambisi untuk melakukan Big Things for God. Tahap kelima ini lebih fokus kepada kerinduan hidup yang lebih nyaman bersama dengan Tuhan. Ini sebuah tahap dimana kita lebih fokus kepada hidup bijaksana yang lahir dari pengalaman dan pengikutan kita kepada Tuhan.

Tahap 6: Tuhan, aku pulang (God, I'm coming home). Sebuah tahapan iman yang bergerak menuju puncak ditandai dengan penyerahan yang terus menerus kepada Tuhan, semua hal di bumi diserahkan kepada-Nya dan kita bersiap untuk kematian. Pada periode ini mungkin banyak mengalami penderitaan fisik dan akan terus kehilangan orang-orang yang dikasihi, namun keyakinan kepada Tuhan merupakan hal yang fundamental dalam kehidupan setiap orang percaya.

Hal yang menarik dan menjadi perhatian bagi orang tua yang sudah lanjut usia adalah ketidaksiapan dalam menghadapi kematian. Dalam pelayanan-pelayanan pastoral seringkali dijumpai bahwa mereka yang sudah ada pada umur-umur tersebut mengalami kegegelisan yang mendalam karena dipengaruhi oleh perbuatan di masa lalu maupun keinginan untuk terus memelihara anak dan cucunya. Alasannya adalah mereka tidak dapat kembali ke dunia dan berkumpul bersama dengan orang-orang yang mereka cintai. ${ }^{35}$

\section{Pendampingan Pastoral dan Keluarga Kepada Orang Tua Lanjut Usia}

Sebelum jauh membahas hal ini, maka perlu kita mengerti kata lanjut usia. Menurut Eliman kata lanjut usia merupakan uangkapan kepada orang tua yang berumur lima puluh ke atas, baik laki-laki maupun perempuan. ${ }^{36}$ Dari pengertian ini, kita dapat memehami

\footnotetext{
35 Ananda Ruth Naftali, Yulius Yusak Ranimpi, and M. Aziz Anwar, "Kesehatan Spiritual Dan Kesiapan Lansia Dalam Menghadapi Kematian," Buletin Psikologi 25, no. 2 (2017): 124-135.

${ }^{36}$ Eliman and Aris Elisa, "Pelayanan Pastoral Bagi Kaum Lansia Ditengah Pandemi Covid-19,"
} 
bahwa orang yang lanjut usia memiliki ciri khas, yaitu adanya penurunan produktifitas, fisik dan psikis. Dengan demikian bahwa pelayanan pastoralan bagi usia sperti ini sangat urgen. Dalam pelayanan pendampingan pastoral merupakan pelayanan yang melibatkan beberapa kegiatan, seperti sustaining (penopangan), healing (pemulihan), compassion (kasih), guiding (penuntunan), dan reconciling (rekonsiliasi) umat terhadap Allah dan sesama. ${ }^{37}$ Kelima hal tersebut harus dipahami oleh hamba Tuhan yang melakukan pendampingan pastoral, selain itu hamba Tuhan juga harus memahami konsep Imago Dei dalam melakukan pendampingan pastoral. Pemahaman-pemaham tersebut harus dikuasai oleh seorang konselor supaya pendampingan yang dilakukan dapat berjalan dengan efektif dan dapat mentransformasikan hidup konseli kepada perubahan yang lebih baik.

Langkah awal dalam melakukan pendampingan pastoral kepada kaum lanjut usia adalah mengerti permasalahan apa yang sedang dihadapi oleh usia ini, kemudian para pelayan di gereja berusaha mengerti kebutuhan apa yang kurang dalam diri orang tua tersebut. Untuk mendapatkan hasil yang akurat kita tidak bisa menggunakan sudut pandang dari kekristenan saja, melainkan kita juga perlu mengintegrasikan berbagai ilmu dalam melakukan pendampingan pastoral, termasuk pengintegrasian dengan ilmu psikologi. ${ }^{38}$

Berdasarkan penjelasan ini, perlu diketahui bersama bahwa ada beberapa persoalan umum yang dialami oleh orang tua yang lanjut usia, yakni: masalah kondisi fisik, kondisi mental, spiritual dan krisis sosial. Keempat hal ini menjadi perhatian para pelayan (konselor) dalam mendampingi, agar orang tua ini tidak selalu mengingat masa lalu tetapi melihat hal ini sebagai fase-fase yang harus dilewati dan dialami oleh semua orang. Sebab menurut Tobing bahwa orang tua yang ada di fase ini mengalami gangguan kecerdasan (kognitif), gerak dan rasa serta gangguan keseimbangan dan koordinansi. ${ }^{39}$ Akibat hal ini, tidak sedikit diantara mereka yang takut dengan kematian dan kesepian. Oleh karena itu ada beberapa langkah penting yang dilakukan dalam mendapingi dan menolong orang tua yang lanjut usia, yaitu:

Pertama, para pelayan (konselor) pentingnya berkunjung dan berdoa. Jadi melalui kegiatan kunjungan ini sangat efektif karena mereka merasa terhibur dan diperhatikan oleh para pelayan melalui kegiatan membaca firman Tuhan dan doa bersama. Aktifitas seperti ini menurut Paende merupakan salah satu tindakan praktis dari hamba-hamba Tuhan untuk penghiburan kepada jemaat yang mengalami rasa kesepian dan dapat teman yang bertukar pikiran atau cerita. ${ }^{40}$ Tetapi dalam melayani orang tua yang lanjut usia mengalami tantangan tersendiri, karena menurut Kristianto bahwa mengajar dan melayani orang dewasa (orang tua) tidak sama dengan mengajarkan anak-anak. Orang tua memiliki pengalaman, latar belakang sosial dan pendidikan yang berbeda-beda. Oleh sebab itu, para

SCRIPTA: Jurnal Teologi dan Pelayanan Kontekstual 9, no. 1 (2020): 1-22.

${ }^{37}$ Bruce L. Petersen, Foundations of Pastoral Care (Nazarene Publishing House, 2013).

${ }^{38}$ Larry Crabb, Konseling Yang Efektif Dan Alkitabiah, ed. Agnes Maria Frances (Yogyakarta: Yayasan Andi, 1995).

${ }^{39}$ S. M. Lumban Tobing, Kecerdasan Pada Usia Lanjut Dan Manusia (Jakarta: Balai Penerbit FKUI, 1995).

${ }^{40}$ Elvin Paende, "Pelayan an Terhadap Jemaat Lanjut Usia Sebagai Pengembanggan Pelayanan Kategorial,” Jurnal Missio Ecclesiae 8, no. 2 (2019): 93-115. 
pelayan harus memperhatikan dan menyesuaikan situasi belajar serta kebutuhan mereka. ${ }^{41}$ Dengan mengkombinasikan beberapa ilmu pengetahuan dengan ilmu teologi dapat memperkaya para konselor dalam menangani dan menganalisis masalah dan kebutuhan yang terdapat pada kaum lanjut usia. Hal yang pertama dan terutama menurut Collins sebenarnya adalah menolong mereka melihat pentingnya membangun hubungan Allah dalam Tuhan Yesus Kristus. Pengakuan dosa dan kesediaan untuk menerima Kristus sebagai Juruselamat secara pribadi, adalah permulaan penyelesaian persoalan kesepian tersebut. $^{42}$

Selain perhatian dari pastoral di atas, yang kedua adalah dukungan keluarga. Dukungan keluarga memegang peranan yang sangat penting untuk dapat memahami situasi dan kondisi orang tua. Dalam kajian yang dilakukan oleh Siahaan menjelaskan bahwa salah satu yang dialami oleh orang tua yang lanjut usai selama ini adalah merasa diabaikan oleh keluarga dan anak. ${ }^{43}$ Jika ini yang terjadi maka sangat bertolak belakang dengan apa yang dikatakan oleh Alkitab "Hormatilah ayahmu dan ibumu, seperti yang diperintahkan kepadamu oleh Tuhan, Allahmu, supaya lanjut umurmu dan baik keadaanmu di tanah yang diberikan Tuhan, Allahmu" (Ul. 5:16; Ef. 1:18a). Prinsip-prinsip ini selalu diabaikan setiap orang bahwa orang tua sangat membutuhkan perhatian, baik dari keluarga, masyarakat maupun gereja. Untuk itu dukuangan dari keluarga dalam memperhatikan orang tua lanjut usia dibutuhkan dengan cara, yaitu berdoa bersama, memberi perhatian melalui kata-kata, memenuhi kebutuhan dan menciptakan suasana rumah tetap kondusif. Dengan keadaan seperti ini maka mereka merasa menikmati kehidupan secara wajar seiring dengan proses penuaan tersebut.

\section{Peranan dan Kedudukan Orang Tua dalam Keluarga dan Gereja}

Pada bagian sebelumnya telah dijelaskan bahwa orang tua memiliki peranan penting dalam keluarga dan gereja. Dalam tulisan ini penulis menguraikan beberapa hal penting berkaitan dengan peranan dan kedudukan orang tua dalam keluarga dan gereja. Salah satu perannya menjadi tiang doa, teladan serta pendidik bagi anak-anaknya. Menurut Puspita, bahwa orang tua yang lanjut usia menjadi panutan, teladan dan penashat (Ay. 15:10; 1 Raj 12:6,8) serta partisipator dalam gereja. ${ }^{44}$ Bila belajar dari kisah Rut dan Naomi menjalani kehidupannya dengan tetap beraktifitas di dalam sebuah lingkungan masyarakat. Naomi tidak menjauhkan diri dari interaksi sosial, demikian juga dengan orang tua seharusnya jangan menjauhkan diri dari hubungan dengan pihak lain seperti keluarga, teman, tetangga bahkan gereja.

Jadi orang tua memiliki tanggung jawab dari berbagai sisi seperti yang telah dijelaskan dalam artikel ini, tetapi sebaliknya gereja memiliki perhatian lebih intens kepada

\footnotetext{
${ }^{41}$ Paulus Lilik Kristianto, Prinsip Dan Praktik Pendidikan Agama Kristen (Yogyakarta: Andi Offset, 2008).

${ }^{42}$ Crabb, Konseling Yang Efektif Dan Alkitabiah.

${ }^{43}$ Ditarya Siahaan, "Pelayanan Pastoral Bagi Lansia Di GKPI Pagar Sinondi Dan HKBP Pardomuan Silangkitang," Jurnal Teologi Cultivation 3, no. 2 (2019): 18-32.

${ }^{44}$ Wiwi Puspita, "Pengembangan Pemuridan Kontekstual Dalam Membina Warga Gereja Lansia," Institut Agama Kristen Negeri Toraja 1, no. 1 (2021): 1-6.
} 
orang tua yang lanjut usia sebagai kaki tangan gereja dalam mendidik jemaat dalam keluarga. Sebab orang tua tidak hanya menjadi pendoa dalam gereja dan keluarga tetapi juga menjadi pendidik dalam keluarga. Dalam Kitab Amsal sangat jelas tugas dari orang tua yakni "Didiklah orang muda menurut jalan yang patut baginya, maka pada masa tuanya pun ia tidak akan menyimpang dari pada jalan itu" (Am. 22:6). Salah satu tugas dan tanggung jawab orang tua, yakni membesar, mendidik, membimbing dan memenuhi kebutuhan dasar anak sesuai dengan firman Allah. Salah satu Kitab Perjanjian Lama yang membahas tentang pendidikan dalam keluarga, yaitu Kitab Ulangan. Kitab Ulangan merupakan bagian akhir kitab Taurat Musa atau Pentateuch. Kitab tersebut mempunyai arti yang besar bagi pembangunan Iman bangsa Israel. ${ }^{45}$

Kitab Ulangan 6: 20 - 25 ini menguraikan beberapa fungsi orang tua sebagai pengajar pertama dalam kehidupan anak-anak dalam keluarga, ${ }^{46}$ yakni: (1) Mengajarkan secara berulang-ulang, (2) Membicarakan di berbagai kesempatan, baik saat santai, bangun tidur maupun dalam perjalanan, (3) Mengajarkan dengan menggunakan tanda pengingat yang berupa tali di tangan, lambing di dahi dan tulisan pada tiang pintu dan pada pintu gerbang. Tujuan dari pengajaran ini adalah supaya anak-anak mengenal Allah yang benar. Bila hal ini dilakukan, maka hal terjadi adalah anak-anak mengalami pertumbuhan dan perkembangan yang meliputi segi fisik, sosial, Psikis dan Spiritual (rohani). ${ }^{47}$ Tetapi yang tidak kalah penting menurut Efrianus Ruli adalah orang tua harus mampu memberi teladan kepada anak melalui tingkah laku dan sikap. ${ }^{48}$ Orang tua harus memberikan contoh atau teladan yang baik bagi anak-anaknya baik itu melalui sikap dan tindakan orang tua dalam kesehariannya, sehingga dapat menjadi panutan yang baik bagi tumbuh kembang seorang anak dalam sebuah keluarga yang sehat dan harmonis baik dari segi jasmani maupun dari segi spiritual. Dengan demikian bahwa peran dan kedudukan orang tua dalam keluarga dan gereja sebagai pendidik merupakan hal penting, karena hanya melalui pendidikan dalam keluarga.

\section{Kesimpulan}

Berdasarkan kajian yang dilakukan oleh penulis dalam tulisan ini, penulis menemukan bahwa peranan dan kedudukan orang tua ditengah keluarga dan gereja sangat penting seperti penjelasan dan uraian dalam tulisan ini. Tidak ada yang bisa menggantikan posisi orang tua dalam keluarga. Dengan pemahaman itu maka orang tua sangat penting diperhatikan dan diberikan ruang bagi mereka dalam melakukan segala aktifitas. Sebab orang tua memiliki tanggung jawab dalam mendidik anggota keluarganya, mempersatukan dan menunjukkan kepemimpinannya sebagai orang tua ditengah keluarga dan gereja. Oleh sebab itu gereja mempunyai tanggung jawab besar dalam membina para orang tua.

\footnotetext{
45 J. Blommmendaal, Pengantar Kepada Perjanjian Lama (Jakarta: BPK. Gunung Mulia, 2008).

${ }^{46} \mathrm{Jl}$ Ch Abineno, Sekitar Katekese Gerejawi (Jakarta: BPK. Gunung Mulia, 1989).

${ }^{47}$ Singgih D. Gunarsa, Dasar Dan Teori Perkembangan Anak (Jakarta: BPK. Gunung Mulia, 2012).

${ }^{48}$ Efrianus Ruli, “Tugas Dan Peran Orang Tua Dalam Mendidik Anak," Jurnal Edukasi Nonformal 1, no. 2 (2020): 143-146.
} 
Dengan pembinaan dan perhatian seperti ini maka asumsi-asumsi yang sering lontarkan selama ini kepada orang tua dapat tepis bahwa orang memang secara fisik tidak dapat diandalkan tetapi kehadiran mereka dalam keluarga dan gereja sebagaimana penjelasan-penjalasan dalam artikel ini sangat berdampak positif bagi keberlangsungan hidup keluarga dan gereja. Oleh sebab itu, tulisan ini sebagai sumbangsih pemikiran baru dalam memperhatikan kehidupan para orang tua sebagaimana pesan-pesan Alkitab, sehingga kajian ini lebih banyak menyoroti aktifitas para orang tua.

\section{Daftar Pustaka}

Abineno, Jl Ch. Sekitar Katekese Gerejawi. Jakarta: BPK. Gunung Mulia, 1989.

Blommmendaal, J. Pengantar Kepada Perjanjian Lama. Jakarta: BPK. Gunung Mulia, 2008.

Bowlby, John. A Secure Base: Clinical Applications of Attachment Theory. USA and Canada: Routledge, 1988.

Crabb, Larry. Konseling Yang Efektif Dan Alkitabiah. Edited by Agnes Maria Frances. Yogyakarta: Yayasan Andi, 1995.

Eliman, and Aris Elisa. "Pelayanan Pastoral Bagi Kaum Lansia Ditengah Pandemi Covid19." SCRIPTA: Jurnal Teologi dan Pelayanan Kontekstual 9, no. 1 (2020): 1-22.

Ezra Tari \& Talizaro Tafonao. "Pendidikan Anak Dalam Keluarga Berdasarkan Kolose 3:21." KURIOS (Jurnal Teologi dan Pendidikan Agama Kristen) 5, no. 1 (2019).

Gunarsa, Singgih D. Dasar Dan Teori Perkembangan Anak. Jakarta: BPK. Gunung Mulia, 2012.

Gunawan, Agung. "Pemuridan Dan Kedewasaan Rohani." Jurnal Theologia Aletheia 19, no. 12 (2017).

Jailani, M. Syahran. "Teori Pendidikan Keluarga Dan Tanggung Jawab Orang Tua Dalam Pendidikan Anak Usia Dini." Nadwa 8, no. 2 (2014): 245.

James, Carolyn Custis. The Gospel of Ruth Loving God Enough to Break the Rules. Michigan: Zondervan, 2011.

Kim, Woo Young. Yesus Jawaban: Kumpulan Kotbah. Jakarta: BPK Gunung Mulia, 2005.

Krismawati, Yeni. "Teori Psikologi Perkembangan Erik H. Erikson Dan Manfaatnya Bagi Tugas Pendidikan Kristen Dewasa Ini.” Kurios 2, no. 1 (2018): 46.

Kristianto, Paulus Lilik. Prinsip Dan Praktik Pendidikan Agama Kristen. Yogyakarta: Andi Offset, 2008.

Loon, Michelle Van. Becoming Sage: Cultivating Meaning, Purpose, and Spirituality in Midlife. Moody Publishers, 2020.

Maxwell, John C. Wisdom from Women in the Bible: Giants of the Faith Speak Into Our Lives. USA: FaithWords, 2015.

Naftali, Ananda Ruth, Yulius Yusak Ranimpi, and M. Aziz Anwar. "Kesehatan Spiritual Dan Kesiapan Lansia Dalam Menghadapi Kematian.” Buletin Psikologi 25, no. 2 (2017): 124-135.

Paende, Elvin. "Pelayan an Terhadap Jemaat Lanjut Usia Sebagai Pengembanggan Pelayanan Kategorial.” Jurnal Missio Ecclesiae 8, no. 2 (2019): 93-115. 
Petersen, Bruce L. Foundations of Pastoral Care. Nazarene Publishing House, 2013.

Puspita, Wiwi. "Pengembangan Pemuridan Kontekstual Dalam Membina Warga Gereja Lansia." Institut Agama Kristen Negeri Toraja 1, no. 1 (2021): 1-6.

Ruli, Efrianus. "Tugas Dan Peran Orang Tua Dalam Mendidik Anak." Jurnal Edukasi Nonformal 1, no. 2 (2020): 143-146.

Sari, Grace Putri Indah. "Peran Gereja Dalam Memperlengkapi Orang Tua Membina Kerohanian Anak.” STT Seminar Alkitab Asia Tenggara, 2018.

Sari, Milya, and Asmendri. "Penelitian Kepustakaan (Library Research) Dalam Penelitian Pendidikan IPA." Penelitian Kepustakaan (Library Research) dalam Penelitian Pendidikan IPA 2, no. 1 (2018): 15.

Saxegaard, Kristin Moen. Character Complexity in the Book of Ruth. Volume 47. Tubingen, Germany: Mohr Siebeck, 2010.

Siahaan, Ditarya. "Pelayanan Pastoral Bagi Lansia Di GKPI Pagar Sinondi Dan HKBP Pardomuan Silangkitang.” Jurnal Teologi Cultivation 3, no. 2 (2019): 18-32.

Sugiyono. "Perspektif Psikologi Keluarga." Journal of Chemical Information and Modeling 53, no. 9 (2013): 1689-1699.

Tafonao, Talizaro. "Pendidikan Kewirausahaan Bagi Warga Gereja Di Era Digital." Visio Dei: Jurnal Teologi Kristen 2, no. 1 (2020): 127-146.

Talizaro Tafonao. "Peran Pendidikan Agama Kristen Dalam Keluarga Terhadap Perilaku Anak." Edudikara: Jurnal Pendidikan dan Pembelajaran 3, no. 2 (2018).

Tobing, S. M. Lumban. Kecerdasan Pada Usia Lanjut Dan Manusia. Jakarta: Balai Penerbit FKUI, 1995.

Wagiu, Nandari Pastica. "Implementasi Peran Orangtua Menurut Ulangan 6:4-9 Dalam PAK Keluarga Di Gereja Masehi Injili Di Minahasa.” Jurnal Shanan 4, no. 2 (2020): $128-161$. 